\title{
Reduction of hydrogen peroxide stress derived from fatty acid beta-oxidation improves fatty acid utilization in Escherichia coli
}

\author{
Hidetaka Doi • Yasushi Hoshino • Kentaro Nakase • \\ Yoshihiro Usuda
}

Received: 14 May 2013 /Revised: 10 October 2013 / Accepted: 10 October 2013 /Published online: 30 October 2013

(C) The Author(s) 2013. This article is published with open access at Springerlink.com

\begin{abstract}
Fatty acids are a promising raw material for substance production because of their highly reduced and anhydrous nature, which can provide higher fermentation yields than sugars. However, they are insoluble in water and are poorly utilized by microbes in industrial fermentation production. We used fatty acids as raw materials for L-lysine fermentation by emulsification and improved the limited fatty acid-utilization ability of Escherichia coli. We obtained a fatty acid-utilizing mutant strain by laboratory evolution and demonstrated that it expressed lower levels of an oxidativestress marker than wild type. The intracellular hydrogen peroxide $\left(\mathrm{H}_{2} \mathrm{O}_{2}\right)$ concentration of a fatty acid-utilizing wildtype $E$. coli strain was higher than that of a glucose-utilizing wild-type $E$. coli strain. The novel mutation $\operatorname{rps} A^{\mathrm{D} 210 \mathrm{Y}}$ identified in our fatty acid-utilizing mutant strain enabled us to promote cell growth, fatty-acid utilization, and L-lysine production from fatty acid. Introduction of this $\operatorname{rps} A^{\mathrm{D} 210 \mathrm{Y}}$ mutation into a wild-type strain resulted in lower $\mathrm{H}_{2} \mathrm{O}_{2}$ concentrations. The overexpression of superoxide dismutase $(\operatorname{sod} A)$ increased intracellular $\mathrm{H}_{2} \mathrm{O}_{2}$ concentrations and inhibited $E$. coli fatty-acid utilization, whereas overexpression of an oxidative-stress regulator (oxyS) decreased intracellular $\mathrm{H}_{2} \mathrm{O}_{2}$ concentrations and promoted $E$. coli fatty acid utilization and L-lysine production. Addition of the reactive oxygen species (ROS) scavenger thiourea promoted L-lysine production from fatty acids and decreased intracellular $\mathrm{H}_{2} \mathrm{O}_{2}$ concentrations. Among the ROS generated by fatty-acid $\beta$ oxidation, $\mathrm{H}_{2} \mathrm{O}_{2}$ critically affected $E$. coli growth and L-lysine production. This indicates that the regression of ROS stress
\end{abstract}

H. Doi $(\bowtie) \cdot$ Y. Hoshino $\cdot$ K. Nakase $\cdot$ Y. Usuda Process Development Laboratories, Research Institute for Bioscience Products \& Fine Chemicals, Ajinomoto Co., Inc, 1-1 Suzuki-cho, Kawasaki-ku, Kawasaki-shi, Kanagawa 210-8681, Japan e-mail: hidetaka_doi@ajinomoto.com promotes fatty acid utilization, which is beneficial for fatty acids used as raw materials in industrial production.

Keywords Escherichia coli · Fatty acid metabolism · Reactive oxygen species · Oxidative stress $\cdot$ Hydrogen peroxide stess $\cdot$ L-Lysine production

\section{Introduction}

Fatty acids are stored as triglycerides within organisms and are an important source of energy as they are both highly reduced and anhydrous. Indeed, the energy yield from $1 \mathrm{~g}$ fatty acid is more than twice that from carbohydrate. However, industrial production by fermentation mainly uses sugars such as glucose and sucrose as raw materials, as fatty acids are insoluble in water and are poorly utilized by producer strains. Recently, biodiesel production from microalgae as a renewable energy source has received considerable attention (Chisti 2007). Commercial microalgae cultures for fatty acid production and the bioconversion of fatty acids to fuels and chemicals by microorganisms are attractive alternative carbon resources for substance production (Chen et al. 2011; Dellomonaco et al. 2010; $\mathrm{Hu}$ et al. 2008; Rosenberg et al. 2008; Service 2009). High-yield aerobic fermentation by Escherichia coli from fatty acids to renewable fuels and chemicals such as ethanol, acetate, acetone, butanol, and propionate has previously been proposed (Dellomonaco et al. 2010), suggesting that fatty acids could become an effective carbon source for industrial production.

$E$. coli is used to produce several industrial primary metabolites, amino acids, and organic acids (Leuchtenberger et al. 2005; Wendisch et al. 2006). Among these, L-lysine is used in food and feed additives and is produced worldwide at quantities of over 1,500,000 metric tons per year. The use of 
this bacterium has economic advantages because of its fast growth and substrate consumption rates. In addition, more biochemical, molecular biological, and post-genomic data are available for these model organisms than for most others.

Fatty acids are assimilated and degraded to acetyl-CoA in $E$. coli by the $\beta$-oxidation-pathway proteins FadL, FadD, FadE, FadB, and FadA under both aerobic and anaerobic conditions (Cronan and Subrahmanyam 1998). All of the E. coli fatty acid $\beta$-oxidation pathway genes ( $f a d L, f a d D, f a d E, f a d B, f a d A$, $f a d I$, and $f a d J$ ) and short-chain fatty acid utilizing genes ( $a t o D$, $a t o A$, and $a t o B$ ) have been identified (Jenkins and Nunn 1987), and most $\beta$-oxidation pathway genes are regulated by FadR (Cronan and Subrahmanyam 1998). FadR also upregulates $f a b A, f a b B$, and $i c l R$ genes and downregulates fad genes ( $f a d L, f a d D, f a d E, f a d B, f a d A, f a d I$, and $f a d J)$ and the usp $A$ gene. $f a b A$ and $f a b B$ are involved in fatty acid synthesis (Magnuson et al. 1993), whereas IclR regulates acetyl-CoA metabolism through aceBA, which encodes glyoxylate shuntpathway enzymes (Resnik et al. 1996). The uspA gene is induced by various stresses, including heat and oxidative (Nachin et al. 2005), and $f a b A$ overexpression decreases the monounsaturated fatty acid content of $E$. coli cell membranes, leading to increased cell resistance to oxidative stress or stress caused by reactive oxygen species (ROS)-generating compounds (Pradenas et al. 2012).

Here, we examined the mechanism of fatty acid degradation by $E$. coli to promote fatty acid utilization. The E. coli genome evolves and adapts to laboratory cultivation conditions (Fong et al. 2005; Herring et al. 2006). We therefore initiated wild-type $E$. coli cultivation for fatty acid utilization on minimal medium supplied with sodium oleate as the sole carbon source. Oleate was used because it is common in vegetable oils and is relatively easy to handle experimentally. We analyzed the physiological phenotype of the $E$. coli mutant obtained that could utilize oleate efficiently and investigated the effects of oxidative stress, especially those caused by ROS-generating compounds, on cell growth and lysine production.

\section{Materials and methods}

Bacterial strains and plasmids All strains, plasmids, and primers used are listed in Table 1. The oxyS gene encoding an oxidative-stress regulator and its promoter region was amplified by the polymerase chain reaction (PCR) using the E. coli MG1655 genome and the primer set oxyS1 (5'-TACCCGGG GATCCTCTAGAGTTCCGCGAGGCGCACCATATTGTT GGTGAA-3') and oxyS2 (5'-TTGCATGCCTGCAGGTCG ACAGAAACGGAGCGGCACCTCTTTTAACCCT-3').

The PCR product was purified with the Wizard SV gel and PCR clean-up system (Promega, Madison, WI), digested by SalI, and cloned into pTWV229 digested by SalI using the In-
Fusion PCR cloning system (Clontech, Mountain View, CA). The resultant plasmid was designated pTWV228-oxyS.

The $\operatorname{sod} A$ gene encoding the superoxide dismutase overexpressing plasmid pTWV229-sodA was constructed as follows. The sodA open reading frame region was amplified using sodA1 (5'-TGATTACGCCAAGCTTAGGAGGTTAA ATGAGCTATACCCTGCCATCCCTGCCGTA-3') and sodA2 (5'- ATCCTCTAGAGTCGACGCGGCCGCTACT TATTTTTTCGCCGCAAAACGTGCCGCTGC-3') primers. The PCR product was purified, digested by Hin dIII and SalI, and cloned into pTWV229 digested with the same restriction enzymes.

Adaptive evolution and analysis of an effective mutation Minimal medium M9 (Miller 1992) supplemented with $1 \mathrm{mM} \mathrm{MgSO}_{4}, 0.1 \mathrm{mM} \mathrm{CaCl}_{2}, 0.001 \%$ thiamine, $0.5 \%$ Tween 80 (polyoxyethylene sorbitan monooleate, CAS:900565-6), and $2 \mathrm{~g} / \mathrm{L}$ sodium oleate was used in adaptive evolution experiments. One loop of $E$. coli MG1655 was inoculated onto an M9 plate and incubated for $20 \mathrm{~h}$ at $37^{\circ} \mathrm{C}$. Cells were cultured in L-shaped test tubes using a TN-2612 rocking incubator (Advantec, Tokyo, Japan) at $37{ }^{\circ} \mathrm{C}$ with constant shaking at $70 \mathrm{rpm}$. The optical density at $600 \mathrm{~nm}$ of the culture was measured continuously, and test-tube cultivation started at approximately $\mathrm{OD}_{600} 0.006$ and finished at $\mathrm{OD}_{600} 0.3$. The culture broth was transferred into fresh minimal medium, and the test-tube cultivation was repeated 22 times for a total cultivation time of $445 \mathrm{~h}$. A single colony was then isolated from the resultant broth spread onto an M9 plate and designated FitnessOle.

The addition of Tween 80 as an emulsifying agent of sodium oleate clarified the medium and allowed us to accurately measure the $\mathrm{OD}_{600}$ in fatty acid supplied medium (Suzuki et al., unpublished data). We ascertained that $E$. coli MG1655 and FitnessOle could not grow and utilize Tween80 as a sole carbon source in test-tube and flask cultivation using M9 medium (data not shown).

The FitnessOle genome was analyzed by whole genome sequencing with an Illumina Genome Analyzer II (GAII; Illumina Inc, San Diego, CA). In order to introduce the $r p s A^{\mathrm{D} 210 \mathrm{Y}}$ mutation into the genomes of other strains, a FitnessOle ycaI deletion mutant was constructed by PCR and the $\lambda$ red deletion method using ycall primer $\left(5^{\prime}-\right.$ agacaaccgctcaacaaagttgcacactttccataaacagggaggggtgcTCTA GACGCTCAAGTTAGTATA-3') and ycaI2 primer (5'gttgtttgtagtgacgccagatactgtgcacgcaggctacaattcggttcAGATCT TGAAGCCTGCTTT-3') as

$y c a I$ is located close to rpsA in the genome. Because $y c a I$ gene is located about $1.7 \mathrm{kbps}$ of $r p s A^{\mathrm{D} 210 \mathrm{Y}}$ mutation in the $E$. coli genome and no significant phenotypes in this study were observed by ycaI gene deletion (data not shown), we can introduce the $r p s A^{\mathrm{D} 210 \mathrm{Y}}$ mutation with $y c a I$ gene deletion by using the phage P1 without phenotypic influence. MG1655 
Table 1 Strains and plasmids

\begin{tabular}{|c|c|c|}
\hline Strain or plasmid & Description, genotype, or sequence & Reference \\
\hline \multicolumn{3}{|l|}{ Strains } \\
\hline MG1655 & $\mathrm{F}-\lambda-i l v G r f b-50 r p h-1$ & CGSC collection number 6300 \\
\hline MG1655 & MG1655 $\Delta y c a I$ deletion mutant constructed by $\lambda$ red system & This study \\
\hline \multicolumn{3}{|l|}{$\Delta y c a I:$ :attR-cat-attL } \\
\hline MG1655rps $A^{\mathrm{D} 210 \mathrm{Y}}$ & MG1655 containing $r p s A^{\mathrm{D} 210 \mathrm{Y}}$ mutation & This study \\
\hline \multicolumn{3}{|l|}{$\Delta y c a I:: a t t R-c a t-a t t L$} \\
\hline FitnessOle & High performance fatty acid-utilizing mutant isolated by adaptive evolution & This study \\
\hline FitnessOle & FitnessOle $\Delta y c a I$ deletion mutant constructed by $\lambda$ red system & This study \\
\hline \multicolumn{3}{|l|}{$\Delta y c a I:: a t t R-c a t-a t t L$} \\
\hline \multirow[t]{2}{*}{ BW25113 } & rrnB3 $\Delta$ lacZ4787 hsdR514 $\Delta($ araBAD $) 567$ & Baba et al. (2006), Keio collection \\
\hline & $\Delta(r h a B A D) 568 r p h-1$ & \\
\hline JW4024 & BW25113 $\Delta$ oxyR::FRT-Kan-FRT; oxyR deletion mutant in BW25113 & Baba et al. (2006), Keio collection \\
\hline JW3933 & BW25113 $\Delta$ soxR::FRT-Kan-FRT; soxR deletion mutant in BW25113 & Baba et al. (2006), Keio collection \\
\hline WC196LC & W3110 NTG mutant (S-aminoethyl-L-cysteine resistant mutant) $\Delta l d c \Delta$ cadA & Kikuchi et al. (1997) \\
\hline WC196LC & WC196LC $\Delta y c a I$ deletion mutant constructed by $\lambda$ red system & This study \\
\hline \multicolumn{3}{|l|}{$\Delta y c a I:: a t t R-c a t-a t t L$} \\
\hline $\mathrm{WC196LC} r p s A^{\mathrm{D} 210 \mathrm{Y}}$ & WC196LC containing $r p s A^{\mathrm{D} 210 \mathrm{Y}}$ mutation & This study \\
\hline \multicolumn{3}{|l|}{$\Delta y c a I:$ :attR-cat-attL } \\
\hline \multicolumn{3}{|l|}{ Plasmids } \\
\hline pTWV228 & Cloning vector, $\mathrm{Ap}^{\mathrm{r}}$ & Takara Bio Inc., Japan \\
\hline pTWV229 & Cloning vector, $\mathrm{Ap}^{\mathrm{r}}$ & Takara Bio Inc., Japan \\
\hline pTWV228-oxyS & oxyS gene on pTWV228 & This study \\
\hline pTWV229-sodA & sodA gene on pTWV229 & This study \\
\hline pCABD2 & $\begin{array}{l}\text { pRSF } 1010 \text { carrying mutated } l_{s} C, \text { mutated } d a p A, \\
\text { mutated } d a p B \text {, and } C \text {. glutamicum } d d h\end{array}$ & Kojima et al. (1994) \\
\hline pKD46 & $\lambda$ red system helper plasmid & Datsenko and Wanner (2000) \\
\hline pMW118- $\lambda$ attL-Cm ${ }^{\mathrm{R}}-\lambda$ attR & $\lambda$ red system vector containing $\mathrm{Cm}^{\mathrm{R}}$ (cat) gene & Katashkina et al. (2005) \\
\hline
\end{tabular}

containing the $r p s A^{\mathrm{D} 210 \mathrm{Y}}$ mutation and WC196LC containing the $r p s A^{\mathrm{D} 210 \mathrm{Y}}$ mutation were constructed by phage P1 transduction using the phage P1 obtained from the FitnessOle ycaI deletion strain.

Statistical testing and estimation of $p$ values The standard error of the mean calculation and a two-tailed unpaired Student's $t$ test were performed using Excel software (Microsoft Corporation, Redmond, WA) from more than three independent samples.

Culture conditions For test-tube cultivation, E. coli MG1655 and its derivative strains were grown overnight at $37^{\circ} \mathrm{C}$ on M9 plates supplemented with $1 \mathrm{mM} \mathrm{MgSO} 4,0.1 \mathrm{mM} \mathrm{CaCl}_{2}$, $0.001 \%$ thiamine, and $2 \mathrm{~g} / \mathrm{L}$ glucose. One loop of the grown cells was inoculated into $10 \mathrm{~mL}$ minimal medium M9 supplemented with $1 \mathrm{mM} \mathrm{MgSO} 4,0.1 \mathrm{mM} \mathrm{CaCl}_{2}$, $0.001 \%$ thiamine, $0.5 \%$ Tween 80 , and $1 \mathrm{~g} / \mathrm{L}$ carbon source (sodium oleate or glucose) in L-shaped test tubes and cultivated at $37{ }^{\circ} \mathrm{C}$ with constant shaking at $70 \mathrm{rpm}$ using a TN-2612 rocking incubator.
For flask cultivation, E. coli MG1655 and its derivative cells grown overnight at $37{ }^{\circ} \mathrm{C}$ on $\mathrm{M} 9$ plates supplemented with $1 \mathrm{mM} \mathrm{MgSO}{ }_{4}, 0.1 \mathrm{mM} \mathrm{CaCl}_{2}$, $0.001 \%$ thiamine, and $2 \mathrm{~g} / \mathrm{L}$ glucose were inoculated into $20 \mathrm{~mL}$ of $\mathrm{M} 9$ medium supplemented with $1 \mathrm{mM}$ $\mathrm{MgSO}_{4}, 0.1 \mathrm{mM} \mathrm{CaCl} 2,0.001 \%$ thiamine, $0.5 \%$ Tween 80 , and $10 \mathrm{~g} / \mathrm{L}$ carbon source (oleic acid, elaidic acid, acetate, maltose, glycerol, or glucose) in a Sakaguchi flask $(500 \mathrm{~mL})$ at an initial $\mathrm{OD}_{600}$ of 0.2 and cultivated at $37{ }^{\circ} \mathrm{C}$ with reciprocal shaking at $120 \mathrm{rpm}$. The $\mathrm{pH}$ of each component was adjusted to 7.0 before sterilization.

For L-lysine fermentation from fatty acids in flasks, E. coli strains derived from WC196LC (Leuchtenberger et al. 2005) were cultivated overnight at $37^{\circ} \mathrm{C}$ on LB plates composed of $1.0 \%$ Bacto tryptone, $0.5 \%$ Bacto yeast extract, $1 \% \mathrm{NaCl}$, and $1.5 \%$ agar. Cells were then inoculated into $40 \mathrm{~mL}$ flaskfermentation medium comprising $2 \mathrm{~g} / \mathrm{L}$ yeast extract, $1 \mathrm{~g} / \mathrm{L}$ $\mathrm{MgSO}_{4} \cdot 7 \mathrm{H}_{2} \mathrm{O}, 24 \mathrm{~g} / \mathrm{L}\left(\mathrm{NH}_{4}\right)_{2} \mathrm{SO}_{4}, 1 \mathrm{~g} / \mathrm{L} \mathrm{KH}_{2} \mathrm{PO}_{4}, 0.01 \mathrm{~g} / \mathrm{L}$ $\mathrm{FeSO}_{4} \cdot 7 \mathrm{H}_{2} \mathrm{O}, 0.082 \mathrm{~g} / \mathrm{L} \mathrm{MnSO}_{4} \cdot 7 \mathrm{H}_{2} \mathrm{O}, 20 \mathrm{~g} / \mathrm{L}$ PIPES, and $10 \mathrm{~g} / \mathrm{L}$ sodium oleate in Erlenmeyer flasks $(500 \mathrm{~mL})$ at an 
initial $\mathrm{OD}_{600}$ of 0.25 . The $\mathrm{pH}$ of the medium was adjusted to 7.0 before sterilization. Fermentation was performed at $37^{\circ} \mathrm{C}$ with rotary shaking at $200 \mathrm{rpm}$.

For L-lysine fermentation from fatty acids in a jar fermenter, E. coli WC196LC and its derivative strains grown overnight at $37^{\circ} \mathrm{C}$ on LB plates were transferred to $300 \mathrm{~mL}$ jar-fermentation medium comprising $2 \mathrm{~g} / \mathrm{L}$ yeast extract, $1 \mathrm{~g} / \mathrm{L}$ $\mathrm{MgSO}_{4} \cdot 7 \mathrm{H}_{2} \mathrm{O}, 24 \mathrm{~g} / \mathrm{L}\left(\mathrm{NH}_{4}\right)_{2} \mathrm{SO}_{4}, 1 \mathrm{~g} / \mathrm{L} \mathrm{KH}_{2} \mathrm{PO}_{4}, 0.01 \mathrm{~g} / \mathrm{L}$ $\mathrm{FeSO}_{4} \cdot 7 \mathrm{H}_{2} \mathrm{O}, 0.082 \mathrm{~g} / \mathrm{L} \mathrm{MnSO}_{4} \cdot 7 \mathrm{H}_{2} \mathrm{O}$, and $10 \mathrm{~g} / \mathrm{L}$ carbon source (sodium oleate or glucose) in 1-L glass vessels (Able Corporation, Tokyo, Japan) at an initial $\mathrm{OD}_{600}$ of 0.04 and subjected to batch cultivation in jar fermenters DPC-2A (Able Corporation, Tokyo, Japan) at $37{ }^{\circ} \mathrm{C}$. The $\mathrm{pH}$ of the culture was maintained at 6.7 by adding ammonia gas.

Analytical methods Aggregation indexes of E. coli MG1655 and the FitnessOle strain were measured as previously described (Malik et al. 2003). Cell growth was analyzed by measuring the $\mathrm{OD}_{600}$ with a spectrophotometer U-2900 (Hitachi, Tokyo, Japan) and by counting the number of living cells. Tween 80 solution $(10 \%)$ was used for dilution to eliminate the influence of fatty acids on $\mathrm{OD}_{600 \mathrm{~nm}}$. Living cell counting in the fermentation broth was carried out by diluting the broth with saline and counting the number of colonies on LB plates after cultivation for $24 \mathrm{~h}$ at $37^{\circ} \mathrm{C}$. The maximum specific growth rate $\left(\mu_{\max }\right)$ and maximum specific substrateconsumption rate $\left(\nu_{\max }\right)$ were calculated by nine-dimension polynomial approximations using the numerical computation software package MATLAB (MathWorks, Natick, MA). $R$ squared values of the approximations were greater than 0.995 .

Carbonylated protein concentrations were measured using a protein carbonyl colorimetric assay kit (Cayman Chemical Company, Ann Arbor, MI). To measure cells in the same growth phase, we sampled the cells from the flaskfermentation broth when the residual carbon source concentration reached $1 \mathrm{~g} / \mathrm{L}$ for the carbonylated protein assay and measured the $\mathrm{OD}_{600}$ to confirm that sampled cells were divided a similar number of times. Glucose and L-lysine were assayed by a biotech analyzer AS310 (Sakura Si Co., Ltd., Tokyo, Japan). Glycerol was assayed by an electrochemical biosensor BF-5 (Oji Scientific Instruments, Hyogo, Japan), maltose by an ion chromatography system ICS-3000 (Dionex, Sunnyvale, CA), acetate by a liquid chromatograph LC-10AD (Shimadzu, Kyoto, Japan), and oleic acid and elaidic acid by a gas chromatograph GC-2014 (Shimadzu).

Intracellular hydrogen peroxide $\left(\mathrm{H}_{2} \mathrm{O}_{2}\right)$ was measured as previously described (González-Flecha and Demple 1999; Maisonneuve et al. 2008). Briefly, bacterial cells were collected from culture broths by centrifugation $(13,800 \times g)$ for $2 \mathrm{~min}$ at $4{ }^{\circ} \mathrm{C}$ and resupended in phosphate buffer $\left(\mathrm{pH} 7.3\right.$ ) at an approximate density of $10^{6}$ cells $/ \mathrm{mL}$. After 10 min diffusion of intracellular $\mathrm{H}_{2} \mathrm{O}_{2}$ into the buffer through cellular membranes, the cells were removed by centrifugation at $13,800 \times g$ for $2 \mathrm{~min}$ at $4{ }^{\circ} \mathrm{C}$. Then, $10 \mu \mathrm{L}$ supernatant was suspended separately in solution A $(2 \mu \mathrm{M}$ horseradish peroxidase and $10 \mu \mathrm{M}$ HPF (Maisonneuve et al. 2008) in $100 \mathrm{mM}$ phosphate buffer $(\mathrm{pH} 7.3))$ and solution $\mathrm{B}(2 \mu \mathrm{M}$ catalase and $10 \mu \mathrm{M}$ HPF (Maisonneuve et al. 2008) in $100 \mathrm{mM}$ phosphate buffer solution ( $\mathrm{pH} 7.3)$ ).

The resusupended samples were incubated at $37{ }^{\circ} \mathrm{C}$ for $75 \mathrm{~min}$ in the dark, and the emitted fluorescence at $515 \mathrm{~nm}$ was measured using excitation at $490 \mathrm{~nm}$. The intracellular $\mathrm{H}_{2} \mathrm{O}_{2}$ concentration was calculated by subtracting the fluorescence of solution $\mathrm{B}$ from that of solution $\mathrm{A}$.

\section{Results}

Acquisition of fatty acid-utilizing E. coli mutant strain by laboratory evolution and analysis of physiological phenotypes To improve fatty acid utilization by $E$. coli, we attempted to obtain a mutant with enhanced function. We cultivated the wild-type $E$. coli strain MG1655 in minimal media supplemented with sodium oleate as a sole carbon source for $445 \mathrm{~h}$. We then isolated a mutant with improved utilization of fatty acid and designated it FitnessOle. Figure 1 shows the growth (Fig. 1a) and oleate concentration (Fig. 1b) profiles of the wild-type and FitnessOle strains in flask culture. The FitnessOle strain showed significantly enhanced growth in oleate culture with enhanced consumption of oleate. We ascertained that four other independent colonies isolated from the same broth after $445 \mathrm{~h}$ cultivation showed the same enhanced growth phenotype as the FitnessOle strain in oleate culture (data not shown). The FitnessOle strain also showed higher $\mu_{\max }$ and $\nu_{\max }$ values when grown on fatty acids (oleic or elaidic acids), glycerol, or acetate as the sole carbon source compared with the wild-type strain (Table 2). The FitnessOle strain also showed increased cell biomass accumulation when grown on oleic acid as the sole carbon source under aerobic conditions compared with the wild-type strain. But the FitnessOle strain showed the same cell biomass accumulation as the wild-type strain when grown on oleic acid under anaerobic conditions (data not shown). Cell aggregation of the FitnessOle strain appeared to be facilitated compared with the wild-type strain. We also measured the aggregation index (Malik et al. 2003) and found the aggregation tendency of the FitnessOle strain to be significantly increased (Fig. 2c).

The usp $A$ gene, encoding a universal stress protein with unknown functions, has been reported to be a target of FadR that is upregulated when $E$. coli is exposed to oxidative stress (Nachin et al. 2005). FadR functions as switch between fatty acid $\beta$-oxidation and fatty acid biosynthesis (Xu et al. 2001). Based on these facts, we investigated the relationship between fatty acid utilization and oxidative stress. We measured the carbonylated protein concentration, a major oxidative-stress 
Fig. 1 The physiological phenotypes of the FitnessOle strain cell growth (a) and residual oleate concentration (b) profiles were measured for MG1655 (solid circle) and FitnessOle strains (solid triangle).

Carbonylated protein content (c) and intracellular hydrogen peroxide concentration (d) were also measured. Values are the mean of more than three independent samples. SE bars represent the standard error of the mean calculated with Excel software a

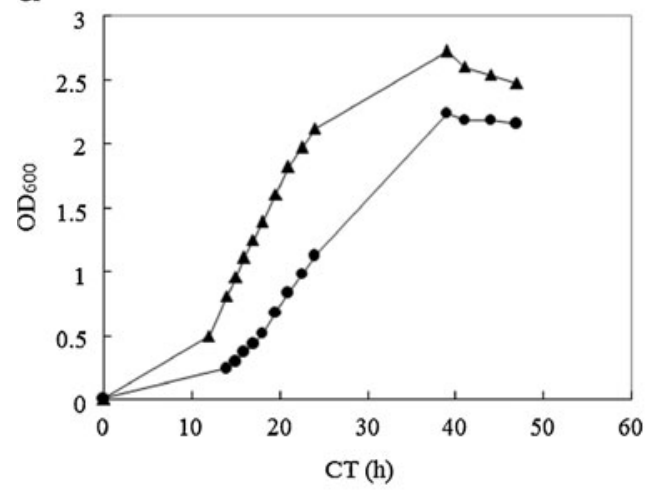

C

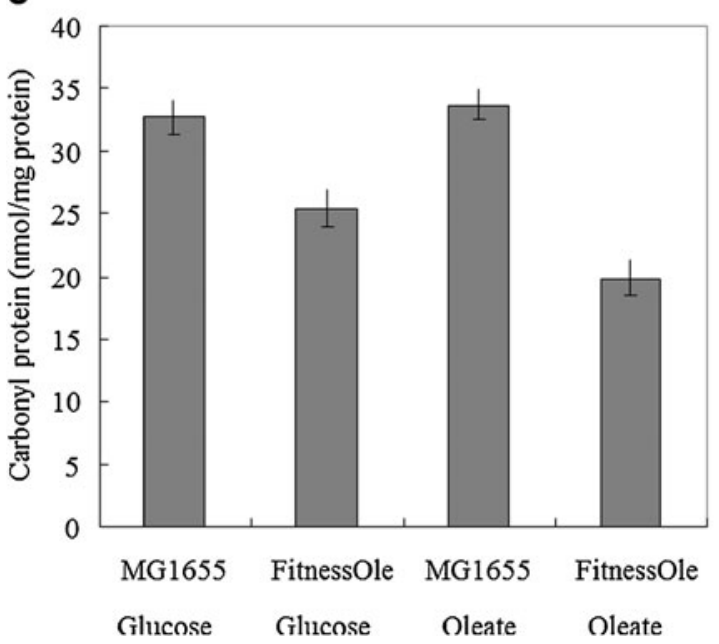

b

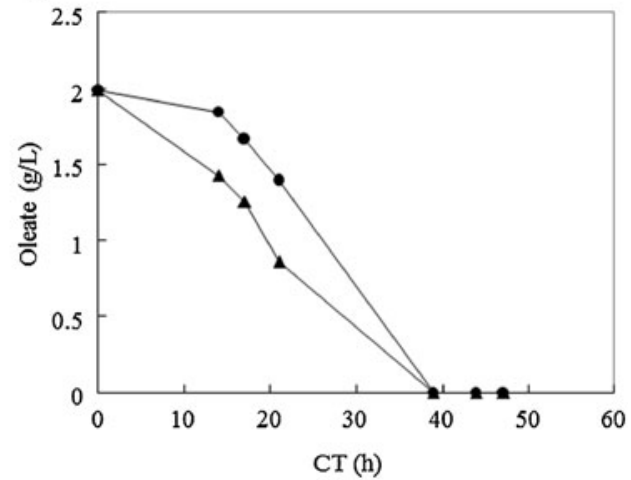

d

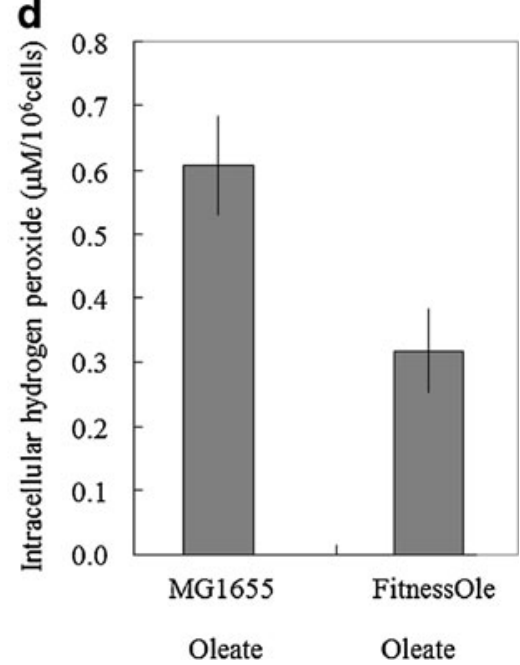

marker, of E. coli cells utilizing glucose or oleate as the sole carbon source (Maisonneuve et al. 2008) and found it to be decreased in the FitnessOle strain compared with wild type after a similar number of cell divisions (Fig. 1c), indicating decreased oxidative stress in this strain. We next measured the concentration of intracellular $\mathrm{H}_{2} \mathrm{O}_{2}$, a major ROS, and also found it to be decreased in the FitnessOle strain compared with wild type when the cells utilized oleate as the sole carbon source (Fig. 1d).

To identify an effective mutation for fatty acid utilization in the genome of the fatty acid-utilizing E. coli mutant strain, we carried out whole genome sequencing and discovered the $r p s A^{\mathrm{D} 210 \mathrm{Y}}$ mutation (Fig. 2a). The $r p s A^{\mathrm{D} 210 \mathrm{Y}}$ mutation was present in the genomes of four other independent colonies isolated from the broth after $445 \mathrm{~h}$ minimal media cultivation. Introduction of this mutation into the MG1655 genome resulted in enhanced cell growth when oleate was used as the sole carbon source (Fig. 2b) and higher $\mu_{\max }$ and $\nu_{\max }$ values than those of the wild-type MG1655. Furthermore, introduction of the $r p s A^{\mathrm{D} 210 \mathrm{Y}}$ mutation caused a decrease in the concentration of intracellular $\mathrm{H}_{2} \mathrm{O}_{2}$ when the strain utilized oleate as a sole carbon source (Fig. 2d) despite no significant change in aggregation index (Fig. 2c). Introduction of the $r p s A^{\mathrm{D} 210 \mathrm{Y}}$ mutation into the genome of the E. coli L-lysine producer strain WC196LC/pCABD2 (Kikuchi et al. 1997) resulted in increased cell growth and L-lysine accumulation (Table 3). There were, however, no apparent differences in Llysine production, cell growth, or glucose consumption
Table $2 \mu_{\max }$ and $\nu_{\max }$ values of the FitnessOle strain in flask cultivation with various carbon sources

$\mu_{\text {max }}$ maximum specific growth rate, $\nu_{\max }$ maximum specific substrate-consumption rate

\begin{tabular}{lllll}
\hline Substrate $(10 \mathrm{~g} / \mathrm{L})$ & $\mu_{\max }$ of MG1655 & $\mu_{\max }$ of FitnessOle & $\nu_{\max }$ of MG1655 & $\nu_{\max }$ of FitnessOle \\
\hline Glucose & 0.85 & 0.85 & 0.63 & 0.63 \\
Glycerol & 0.62 & 0.81 & 0.40 & 0.59 \\
Maltose & 0.44 & 0.41 & 0.30 & 0.29 \\
Oleic acid & 0.09 & 0.24 & 0.06 & 0.12 \\
Elaidic acid & 0.11 & 0.23 & 0.07 & 0.12 \\
Acetate & 0.09 & 0.11 & 0.07 & 0.08 \\
\hline
\end{tabular}


Fig. 2 DNA and amino acid sequence of $r p s A^{\mathrm{D} 210 \mathrm{Y}}$ mutation (a) and its effect on fatty acid utilization. b Growth of the $r p s A^{\mathrm{D} 210 \mathrm{Y}}$ mutant strain in M9 medium test tube cultivation supplemented with sodium oleate as the sole carbon source. Parental strain MG1655 (solid circle), FitnessOle strain (solid triangle), MG1655 $\Delta y c a I:: a t t R-c a t-a t t L$ strain (solid square) and MG1655 $r p s A^{\mathrm{D} 210 \mathrm{Y}} \Delta y c a I::$ attR-cat-attL strain (empty diamond) were monitored. Aggregation index (c) and intracellular hydrogen peroxide concentration (d) of cells cultivated in M9 medium supplemented with sodium oleate as a sole carbon source were also measured. Values are the mean of more than three independent samples. $S E$ bars represent the standard error of the mean calculated with Excel software
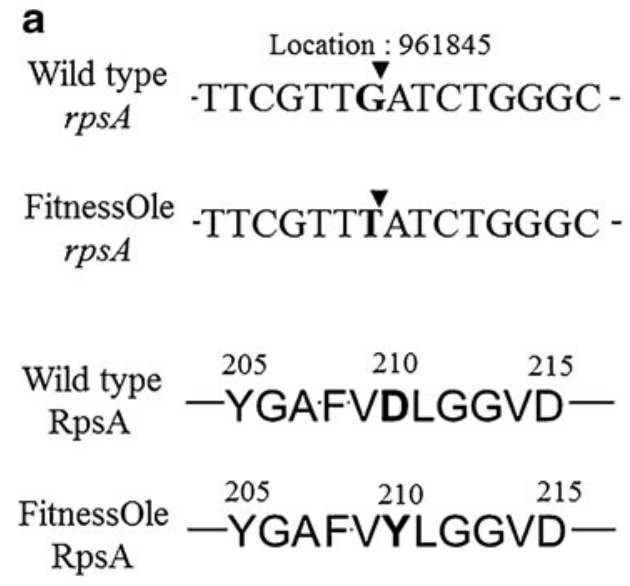

C

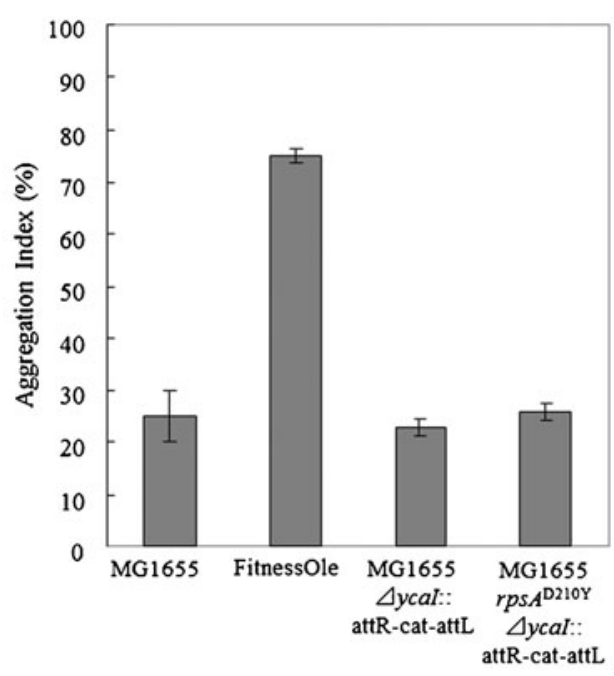

b

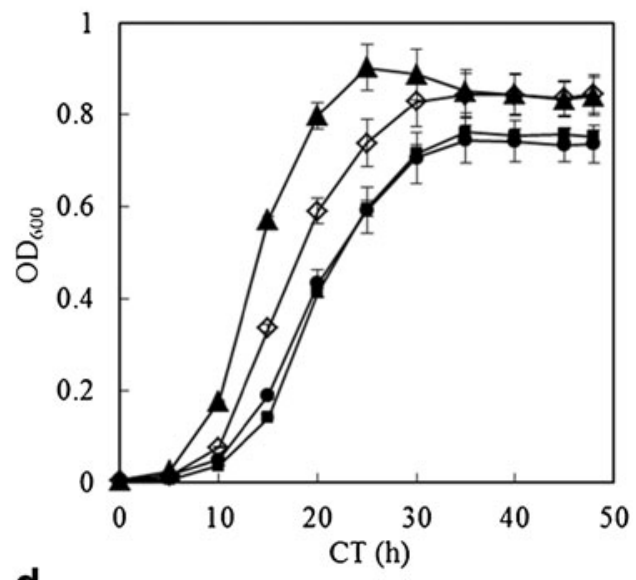

d

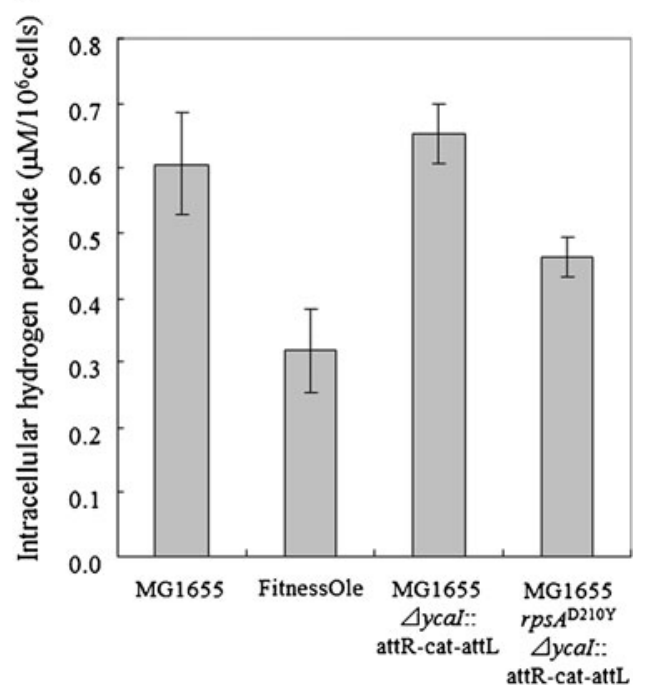

following introduction of the $\operatorname{rps} A^{\mathrm{D} 210 \mathrm{Y}}$ mutation when the $E$. coli L-lysine producer strain utilized glucose (Table 3).

Promotion of fatty acid utilization by reducing intracellular $\mathrm{H}_{2} \mathrm{O}_{2}$ In the wild-type strain MG1655, no carbon source (glucose or oleate)-dependent changes in carbonylated protein accumulation were observed (Fig. 1c), suggesting that the specific ROS stress was decreased only in the fatty acidutilizing mutant FitnessOle strain. As shown in Fig. 3, the ROS consists of a single oxygen molecule, a superoxide anion $\left(\mathrm{O}_{2}{ }^{-}\right), \mathrm{H}_{2} \mathrm{O}_{2}$, and a hydroxyl radical ( $\left.\mathrm{OH}\right)$ (González-Flecha and Demple 1999; Blanchard et al. 2007; Zheng et al. 1998). The two transcription factors reported to respond to $\mathrm{O}_{2}{ }^{-}$and $\mathrm{H}_{2} \mathrm{O}_{2}$ are also shown (Blanchard et al. 2007; Zheng et al. 1998). SoxR is mainly involved in defense against $\mathrm{O}_{2}{ }^{-}$and OxyR mainly against $\mathrm{H}_{2} \mathrm{O}_{2}$. Thus, we investigated the growth of the $\operatorname{soxR}$ deletion mutant (JW3933) and the $\operatorname{oxy} R$ deletion mutant (JW4024) derived from BW25113 (Baba et al. 2006) on glucose or oleate as the sole carbon source. Both the $\Delta \operatorname{sox} R$ and $\Delta \operatorname{oxy} R$ strains showed no significant stationary phase optical density changes compared with their host strain BW25113 when they utilized glucose as the sole carbon source (Fig. 4a). However, the $\Delta$ oxyR strain showed an apparent cell growth defect and a stationary phase optical density decrease when grown on sodium oleate as the sole carbon source (Fig. 4b).

To determine which ROS has the greatest negative effect on fatty acid utilization in $E$. coli, we constructed expression plasmids harboring the $\operatorname{sod} A$ gene encoding the $\mathrm{O}_{2}{ }^{-}$ scavenger dismutase or the oxyS gene encoding an oxidative-stress regulator and introduced them into the wildtype strain MG1655. The oxyS transcript might be involved in the excretion, rather than removal, of $\mathrm{H}_{2} \mathrm{O}_{2}$ by catalase peroxidases (González-Flecha and Demple 1999). The resultant strains (MG1655/pTWV229-sodA and MG1655/ pTWV228-oxyS) were cultivated on glucose or sodium oleate as a carbon source (Fig. 5). The intracellular $\mathrm{H}_{2} \mathrm{O}_{2}$ concentration was significantly increased when the $E$. coli MG1655/pTWV228 strain utilized sodium oleate compared with glucose as the sole carbon source (Fig. 5a, b; $p<0.03$, 
Table 3 Effect of $r p s A^{\mathrm{D} 210 \mathrm{Y}}$ mutation on L-lysine production in flask cultivation from fatty acid (sodium oleate)

\begin{tabular}{|c|c|c|c|c|}
\hline Strain & Carbon source & $\mathrm{OD}_{600}$ & $\begin{array}{l}\text { L-Lysine } \\
\text { accumulation }(\mathrm{g} / \mathrm{L})\end{array}$ & $\begin{array}{l}\text { L-Lysine } \\
\text { yield (\%) }\end{array}$ \\
\hline WC196LC/pCABD2 & Glucose & 5.5 & 3.8 & 39.0 \\
\hline $\begin{array}{l}\text { WC196LC } \\
\Delta y c a I:: \text { attR-cat-attL/pCABD2 }\end{array}$ & Glucose & 5.5 & 3.8 & 39.2 \\
\hline $\begin{array}{l}\text { WC196LC } \\
r p s A^{\mathrm{D} 210 \mathrm{Y}} \\
\Delta y c a I:: \text { attR-cat-attL/pCABD2 }\end{array}$ & Glucose & 5.5 & 3.8 & 39.0 \\
\hline WC196LC/pCABD2 & Oleate & 8.1 & 4.2 & 44.9 \\
\hline $\begin{array}{l}\text { WC196LC } \\
\Delta y c a I:: \text { attR-cat-attL/pCABD2 }\end{array}$ & Oleate & 8.3 & 4.2 & 44.8 \\
\hline $\begin{array}{l}\text { WC196LC } \\
r p s A^{\mathrm{D} 210 \mathrm{Y}} \\
\Delta y c a I:: \text { attR-cat-attL/pCABD2 }\end{array}$ & Oleate & 9.3 & 4.5 & 47.2 \\
\hline
\end{tabular}

Student's $t$ test). Furthermore, overexpression of the $\operatorname{sod} A$ gene resulted in an increase of intracellular $\mathrm{H}_{2} \mathrm{O}_{2}$ and a severe growth defect (Fig. 5b, d). Overexpression of the oxyS gene decreased intracellular $\mathrm{H}_{2} \mathrm{O}_{2}$ levels and promoted cell growth (Fig. 5b, d).

\section{Effects of promotion of fatty acid utilization by reducing ROS} stress on L-lysine production To investigate the relationship between material production from fatty acids and reduction of ROS stress, we used the E. coli L-lysine-producing strain WC196LC/pCABD2 (Kikuchi et al. 1997). Overexpression

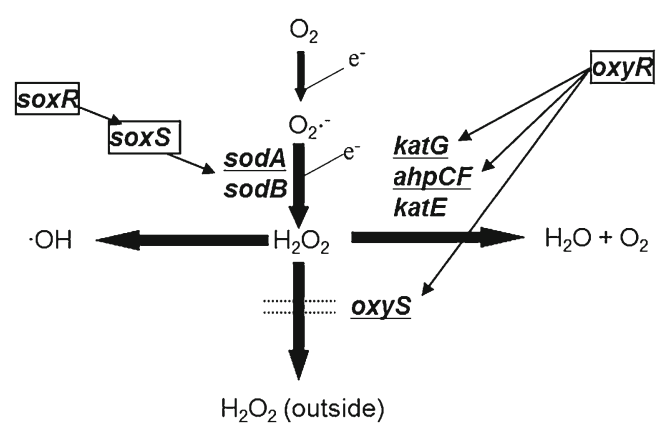

Fig. 3 Schematic representation of ROS generation and elimination, and transcriptional regulation of ROS elimination systems in E. coli. Ordinary electron transfer to an oxygen molecule converting into a water molecule is catalyzed by cytochrome oxidases, but incomplete electron transfer to an oxygen molecule generates $\mathrm{O}_{2}{ }^{-}, \mathrm{H}_{2} \mathrm{O}_{2}$, and $\mathrm{OH}^{-}$. These ROS molecules cause cell damage so $E$. coli possesses various $\mathrm{ROS}$ scavenger genes. Superoxide dismutases ( $\mathrm{SodA}$ and $\mathrm{SodB}$ ) convert $\mathrm{O}_{2}{ }^{--}$into $\mathrm{H}_{2} \mathrm{O}_{2}$, which decomposes into harmless $\mathrm{H}_{2} \mathrm{O}$ and $\mathrm{O}_{2}$ with the aid of catalases $\mathrm{KatG}$, KatE, and the alkyl hydroxiperoxide reductase AhpCF. Intracellular $\mathrm{H}_{2} \mathrm{O}_{2}$ excretion is promoted by small RNA oxyS. These ROS-scavenger genes are regulated by SoxR and OxyR. SoxR detects intracellular $\mathrm{O}_{2}{ }^{-}$and upregulates SoxS expression. SoxR and SoxS activate $\mathrm{O}_{2}{ }^{-}$decomposing genes such as $\operatorname{sod} A$ and $\operatorname{sod} B$. OxyR is an intracellular $\mathrm{H}_{2} \mathrm{O}_{2}$ sensor and $\mathrm{H}_{2} \mathrm{O}_{2}$ removal-associated gene regulator. OxyR activates oxyS and $\mathrm{H}_{2} \mathrm{O}_{2}$-decomposing genes such as kat $G$, katE, and $a h p C F$ of oxyS in WC196LC/pCABD2 resulted in increased cell growth and L-lysine accumulation (Table 4). This suggests that decreased ROS stress, assumed to be mainly caused by intracellular $\mathrm{H}_{2} \mathrm{O}_{2}$, promoted fatty acid utilization and Llysine production. Next, we investigated the effect of the antioxidant reagent thiourea on fatty acid utilization in larger scale fermentation. Thiourea reduces damage caused by $\mathrm{H}_{2} \mathrm{O}_{2}$ (Blount et al. 1989) and was shown to decrease intracellular $\mathrm{H}_{2} \mathrm{O}_{2}$ concentrations both in glucose and sodium oleate utilization (Table 5). However, thiourea also reduced the cultivation times required to consume fatty acid and increased cell and L-lysine accumulation when the $E$. coli L-lysine-producing strain utilized sodium oleate (Table 5). No apparent differences in L-lysine production, cell growth, or glucose consumption were observed following thiourea addition when the $E$. coli L-lysine producer strain utilized glucose (Table 5).

\section{Discussion}

We predicted that test-tube adaptive evolution would shed light on fatty acid utilization in $E$. coli by comparing physiological phenotype differences between a mutant that can utilize fatty acids efficiently and a wild-type strain. Indeed, the mutant strain FitnessOle showed a higher ability to utilize various fatty acids, including oleic acid, elaidic acid (Table 2), stearic acid, sodium palmitate, myristic acid, and sodium oleate (data not shown), compared with wild type.

The FitnessOle strain showed enhanced cell aggregation as well as lowered ROS stress (Fig. 2). Microorganism aggregation can be quantified by measurement of the aggregation index and is positively correlated with membrane hydrophobicity (Malik et al. 2003). Thus, our results indicate that the FitnessOle strain possesses increased membrane 
Fig. 4 The effects of antioxidant transcription factor gene deletion. The growth of $\Delta \operatorname{sox} R$ and $\Delta$ oxy $R$ strains in M9 medium test tube cultivation supplemented with sodium glucose (a) or oleate (b) as the sole carbon source. Parental strain BW25113 (solid circle), $\triangle \operatorname{oxy} R$ strain (solid triangle), and $\Delta$ soxR strain (solid square) were monitored. Values are the mean of more than three independent samples. $S E$ bars represent the standard error of the mean calculated with Excel software a

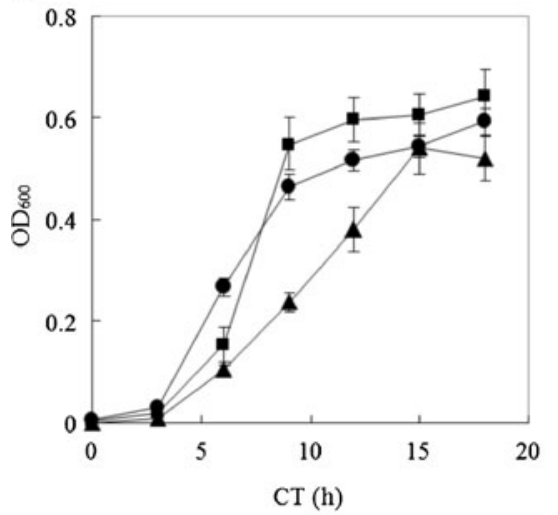

b

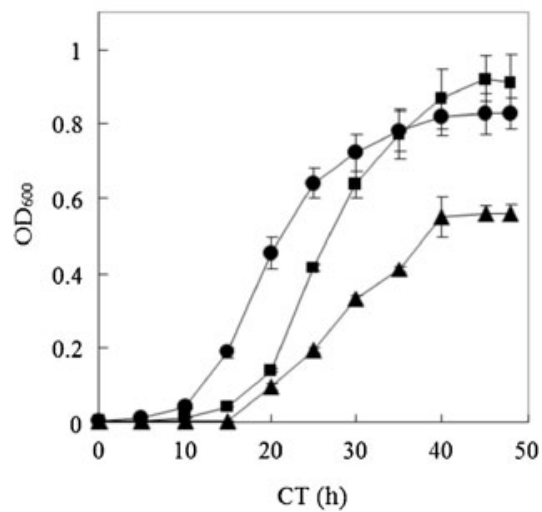

hydrophobicity; we will examine this together with its relationship with fatty acid utilization in a future study.

Our main focus here was the promotion of fatty acid utilization in $E$. coli. We discovered a novel fatty acid utilization promoting mutation, $r p s A^{\mathrm{D} 210 \mathrm{Y}} \cdot \operatorname{rps} A$ encodes the $30 \mathrm{~S}$ ribosomal subunit protein. Introduction of the $\operatorname{rps} A^{\mathrm{D} 210 \mathrm{Y}}$ mutation decreased intracellular $\mathrm{H}_{2} \mathrm{O}_{2}$ concentrations (Fig. 2d) but had no effect on cell aggregation (Fig. 2c). These results suggest that intracellular $\mathrm{H}_{2} \mathrm{O}_{2}$ concentrations can influence fatty acid utilization. We also found that a decrease in ROS stress, particularly that of $\mathrm{H}_{2} \mathrm{O}_{2}$, was important to enhance the ability to utilize fatty acid in E. coli. However, as the ROS was shown to change (Fig. 3), it is difficult to identify which species affects fatty acid utilization. Nevertheless, our research revealed that it was mainly inhibited by $\mathrm{H}_{2} \mathrm{O}_{2}$ rather than $\mathrm{O}_{2}{ }^{-}$(Figs. 4 and 5). There were no apparent changes for the carbonylated
Fig. 5 Effects of overexpression of $\operatorname{sodA}$ or $\operatorname{oxy} S$ genes. Intracellular hydrogen peroxide concentration of cells grown in M9 medium supplemented with glucose (a) or sodium oleate (b) as the sole carbon source. Cell growth using glucose (c) or sodium oleate (d) as the sole carbon source. Vector control MG1655/pTWV228 (solid circle), oxyS overexpressing strain MG1655/pTWV228-oxyS (solid triangle) and sodA overexpressing strain MG1655/ pTWV229-sodA (solid square) were studied. Values are the mean of more than three independent samples. $S E$ bars represent the standard error of the mean calculated with Excel software. The Student's $t$ test between the intracellular hydrogen peroxide concentration of vector control samples and that of oxyS overexpression samples when grown on sodium oleate gave a $p$ value of 0.024 a

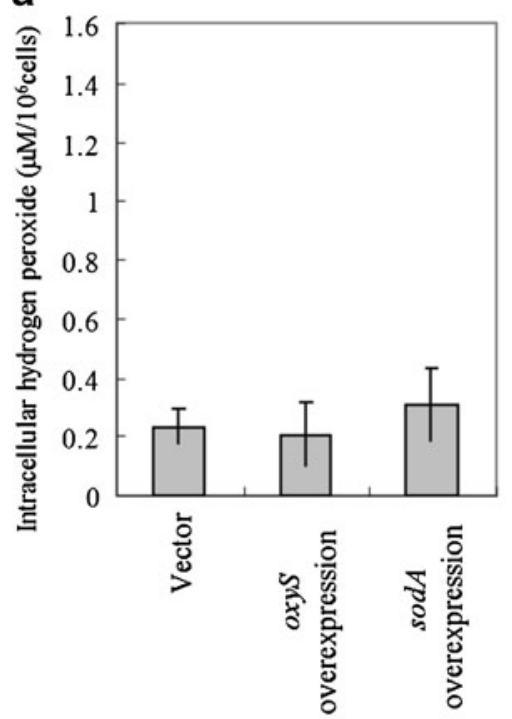

C

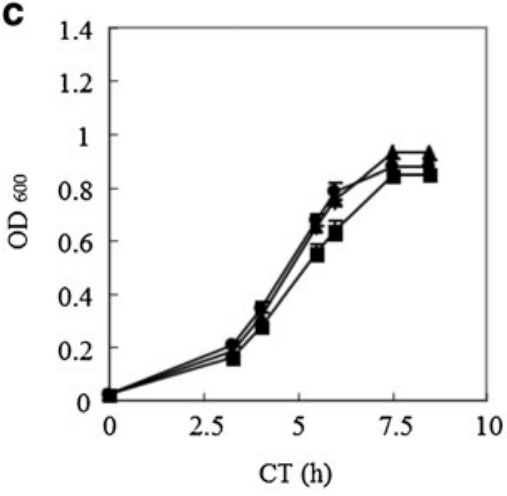

b

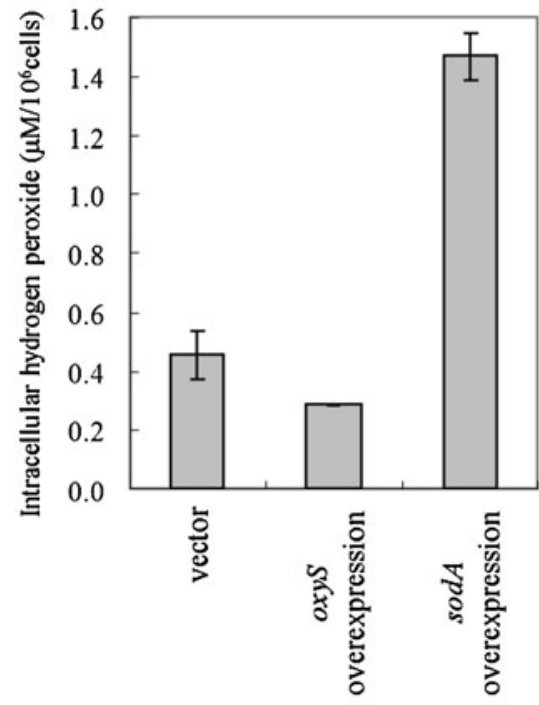

d

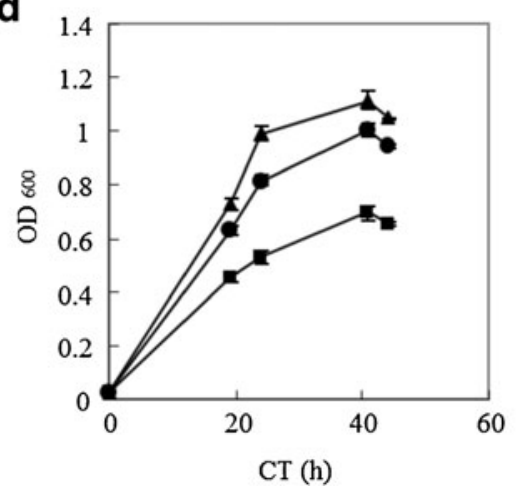


Table 4 Effect of $\operatorname{oxy} S$ gene overexpression on L-lysine production in flask cultivation from fatty acid (sodium oleate)

\begin{tabular}{lllll}
\hline Strain & $\mathrm{OD}_{600}$ & $\begin{array}{l}\text { L-Lysine } \\
\text { accumulation }(\mathrm{g} / \mathrm{L})\end{array}$ & $\begin{array}{l}\text { L-Lysine yield } \\
\text { from oleate }(\%)\end{array}$ & $\begin{array}{l}\text { Intracellular } \mathrm{H}_{2} \mathrm{O}_{2} \\
\left(\mu \mathrm{M} / 10^{6} \text { cells }\right)\end{array}$ \\
\hline WC196LC/pCABD2, pTWV228 & 4.3 & 3.8 & 40.9 & 0.52 \\
WC196LC/pCABD2, pTWV228-oxyS & 6.2 & 4.2 & 45.3 & 0.26 \\
\hline
\end{tabular}

protein accumulation in wild-type E. coli cells grown in M9 media with glucose or oleate (Fig. 1c). On the other hand, the intracellular $\mathrm{H}_{2} \mathrm{O}_{2}$ concentration was significantly increased when the wild-type strain utilized sodium oleate compared with glucose as the sole carbon source (Fig. 5a, b). Carbonylated protein content indicates total ROS stress including, $\mathrm{H}_{2} \mathrm{O}_{2}, \mathrm{O}_{2}{ }^{-}$, and $\mathrm{OH}$ (Fig. 3). These data show that the specific ROS stress is $\mathrm{H}_{2} \mathrm{O}_{2}$ stress when $E$. coli utilized sodium oleate among the various ROS. Our preliminary microarray research revealed that $k a t G, \operatorname{ahpC}, \operatorname{ahpF}$, and $\operatorname{oxy} R$ transcripts were increased in FitnessOle strain compared with the wild type when they utilized sodium oleate (Doi et al., unpublished data). In addition, our preliminary microarray research also revealed that $\operatorname{sod} A$, $\operatorname{sod} B$, $\operatorname{sox} S$, and $\operatorname{sox} R$ transcripts were decreased in FitnessOle strain compared with the wild type when they utilized sodium oleate (Doi et al., unpublished data). These results indicate the independence of $\mathrm{H}_{2} \mathrm{O}_{2}$ and $\mathrm{O}_{2}{ }^{-}$. No significant phenotype was previously reported following the overexpression of oxyS when $E$. coli was cultivated on LB, in which the main carbon source was amino acids not fatty acids (González-Flecha and Demple 1999).

Similarly, no significant phenotype was observed by the overexpression of $\operatorname{xyy} S$ when $E$. coli utilized glucose as the main carbon source (Fig. 5a, c). However, we did observe the promotion of fatty acid utilization following oxyS overexpression, presumably because of reduced $\mathrm{H}_{2} \mathrm{O}_{2}$ levels (Fig. 5b and d) and L-lysine production (Table 4). We assumed that this effect was a result of $\mathrm{H}_{2} \mathrm{O}_{2}$ excretion by the oxyS transcript (González-Flecha and Demple 1999). These results demonstrate a specific phenotype after oxyS overexpression and suggest that more $\mathrm{H}_{2} \mathrm{O}_{2}$ is generated when utilizing fatty acid compared with glucose and amino acids supplied in LB medium. We presume that $\mathrm{H}_{2} \mathrm{O}_{2}$ is generated by flavin adenine dinucleotide $\left(\mathrm{FADH}_{2}\right)$ during the fatty acid $\beta$ oxidation pathway.

This autoxidation of $\mathrm{FADH}_{2}$ is a well-known phenomenon that occurs, for example, in glucose concentration analysis by glucose oxidase (Raba and Mottola 1995). Free $\mathrm{FADH}_{2}$ was previously shown to be reduced by cytosolic enzymes such as L-aspartate oxidase and was autoxidized to generate endogenous E. coli $\mathrm{H}_{2} \mathrm{O}_{2}$ (Korshunov and Imlay 2010; Messner and Imlay 2002). We assumed that $\mathrm{FADH}_{2}$ reduced by FadE, the acyl-CoA dehydrogenase in the fatty acid $\beta$ oxidation pathway, would be the endogenous $\mathrm{H}_{2} \mathrm{O}_{2}$ source in the present study. We are currently investigating the effects of $\mathrm{FADH}_{2}$ oxidation by electron-transfer-flavoprotein (ETF) or ETF dehydrogenase (EC 1.5.5.1). Our preliminary research revealed that the overexpression of these homologous genes in E. coli results in the decrease of intracellular $\mathrm{H}_{2} \mathrm{O}_{2}$ and increased $\mathrm{L}$-lysine accumulation during the utilization of fatty acid as a carbon source (Hoshino et al., unpublished data), supporting our hypothesis of endogenous $\mathrm{H}_{2} \mathrm{O}_{2}$ generation by $\mathrm{FADH}_{2}$ autoxidation.

In jar fermentation, thiourea addition decreased intracellular $\mathrm{H}_{2} \mathrm{O}_{2}$ concentrations, lowered cultivation time, and increased L-lysine production when $E$. coli utilized fatty acid (Table 5). However, when glucose was utilized, the total cultivation time and L-lysine production remained the same, even though intracellular $\mathrm{H}_{2} \mathrm{O}_{2}$ concentrations decreased (Table 5). This
Table 5 Effects of ROSscavenger addition on L-lysine production

The L-lysine producing strain, WC196LC/pCABD2, was cultivated in a jar fermenter, and the intracellular $\mathrm{H}_{2} \mathrm{O}_{2}$ concentration was measured immediately after the exhaustion of carbon sources

\begin{tabular}{lllll}
\hline $\begin{array}{l}\text { Supplied carbon source } \\
\text { and antioxidant }\end{array}$ & $\begin{array}{l}\text { Cultivation } \\
\text { time }(\mathrm{h})\end{array}$ & $\mathrm{OD}_{600}$ & $\begin{array}{l}\text { L-Lysine } \\
\text { accumulation }(\mathrm{g} / \mathrm{L})\end{array}$ & $\begin{array}{l}\text { Intracellular } \mathrm{H}_{2} \mathrm{O}_{2} \\
\left(\mu \mathrm{M} / 10^{6} \text { cells }\right)\end{array}$ \\
\hline $\begin{array}{l}\text { Glucose } 10 \mathrm{~g} / \mathrm{L} \\
\text { Glucose } 10 \mathrm{~g} / \mathrm{L}\end{array}$ & 16.0 & 5.3 & 4.7 & 0.14 \\
$\begin{array}{l}\text { Thiourea } 1 \mathrm{mM} \\
\text { Glucose } 10 \mathrm{~g} / \mathrm{L}\end{array}$ & 16.0 & 5.3 & 4.7 & 0.11 \\
$\begin{array}{l}\text { Urea } 1 \mathrm{mM}(\mathrm{mock} \text { control) } \\
\text { Sodium oleate } 10 \mathrm{~g} / \mathrm{L}\end{array}$ & 16.0 & 5.2 & 4.6 & 0.14 \\
$\begin{array}{l}\text { Sodium oleate } 10 \mathrm{~g} / \mathrm{L} \\
\text { Thiourea } 1 \mathrm{mM}\end{array}$ & 33.0 & 6.8 & 4.8 & 0.17 \\
$\begin{array}{l}\text { Sodium oleate } 10 \mathrm{~g} / \mathrm{L} \\
\text { Urea } 1 \mathrm{mM}(\mathrm{mock} \text { control) }\end{array}$ & 41.5 & 7.3 & 5.2 & 0.11 \\
\hline
\end{tabular}


suggests that higher ROS stress was generated following fatty acid utilization, which inhibited growth. The addition of thiourea, a common antioxidant molecule, to reduce ROS stress is a promising approach for fatty acids used on an industrial scale as raw materials for fermentation. Thiourea is used as a building material because it is inexpensive compared with antioxidants such as vitamin $\mathrm{C}$ or tocopherol.

The present study focused only on the physiological phenotype of the FitnessOle strain and identified a novel mutation, $r p s A^{\mathrm{D} 210 \mathrm{Y}}$. We are currently using this mutation to understand the mechanism of decreasing intracellular $\mathrm{H}_{2} \mathrm{O}_{2}$ concentrations. Our preliminary data revealed that superoxide dismutase SodB protein expression decreased following the introduction of the $\operatorname{rps} A^{\mathrm{D} 210 \mathrm{Y}}$ mutation, as shown by 2-D electrophoresis and liquid chromatography-mass spectrometry analysis (Doi et al., unpublished data). However, the $r p s A^{\mathrm{D} 210 \mathrm{Y}}$ mutation alone could not achieve the increased cell growth and decreased intracellular $\mathrm{H}_{2} \mathrm{O}_{2}$ concentration shown by the FitnessOle strain. Therefore, we are now investigating the other mutations of the FitnessOle genome, which should reveal more information concerning $E$. coli fatty acid utilization. We expect this to clarify the relationship between the reduction of ROS and changes in membrane hydrophobicity.

Fatty acids are a promising raw material for substance production, and we have shown that they can be used as such for amino acid fermentation by means of emulsification, despite their insolubility in water (Suzuki et al., unpublished data). This report is the first to show the bioconversion of fatty acid into Llysine by obtaining a fatty acid-utilizing mutant, the FitnessOle strain. $\mathrm{H}_{2} \mathrm{O}_{2}$ generated by fatty acid $\beta$-oxidation was revealed to have a critical effect on growth and lysine production when $E$. coli utilized fatty acid as a carbon source. This will be useful for future industrial production using fatty acids as substrates, and we hope to identify further useful insights to help in the realization of this process.

Acknowledgments The authors thank S. Suzuki, H. Kobayashi, and M. Sada for providing unpublished information about cultivation methods using fatty acids as carbon sources. We are also grateful to $\mathrm{H}$. Motokawa and S. Fukai for excellent technical assistance.

Open Access This article is distributed under the terms of the Creative Commons Attribution License which permits any use, distribution, and reproduction in any medium, provided the original author(s) and the source are credited.

\section{References}

Baba T, Ara T, Hasegawa M, Takai Y, Okumura Y, Baba M, Datsenko KA, Tomita M, Wanner BL, Mori H (2006) Construction of Escherichia coli K-12 in-frame, single-gene knockout mutants: the Keio collection. Mol Syst Biol 2:2006.0008

Blanchard JL, Wholey WY, Conlon EM, Pomposiello PJ (2007) Rapid changes in gene expression dynamics in response to superoxide reveal SoxRS-dependent and independent transcriptional networks. PLoS ONE 11:e1186

Blount S, Griffiths HR, Lunec J (1989) Reactive oxygen species induce antigenic changes in DNA. FEBS Lett 245(1):100-104

Chen CY, Yeh KL, Aisyah R, Lee DJ, Chang JS (2011) Cultivation, photobioreactor design and harvesting of microalgae for biodiesel production: a critical review. Bioresour Technol 102(1):71-81

Chisti Y (2007) Biodiesel from microalgae. Biotechnol Adv 25:294-306

Cronan JE Jr, Subrahmanyam S (1998) FadR, transcriptional coordination of metabolic expediency. Mol Microbiol 29(4):937-943

Datsenko KA, Wanner BL (2000) One-step inactivation of chromosomal genes in Escherichia coli K-12 using PCR products. Proc Natl Acad Sci U S A 97(12):6640-6645

Dellomonaco C, Rivera C, Campbell P, Gonzalez R (2010) Engineered respiro-fermentative metabolism for the production of biofuels and biochemicals from fatty acid-rich feedstocks. Appl Environ Microbiol 76(15):5067-5078

Fong SS, Joyce AR, Palsson BO (2005) Parallel adaptive evolution cultures of Escherichia coli lead to convergent growth phenotypes with different gene expression states. Genome Res 15(10):1365-1372

González-Flecha B, Demple B (1999) Role for the oxyS gene in regulation of intracellular hydrogen peroxide in Escherichia coli. J Bacteriol 181(12):3833-3836

Herring CD, Raghunathan A, Honisch C, Patel T, Applebee MK, Joyce AR, Albert TJ, Blattner FR, van den Boom D, Cantor CR, Palsson BO (2006) Comparative genome sequencing of Escherichia coli allows observation of bacterial evolution on a laboratory timescale. Nat Genet 38(12):1406-1412

$\mathrm{Hu}$ Q, Sommerfeld M, Jarvis E, Ghirardi M, Posewitz M, Seibert M, Darzins A (2008) Microalgal triacylglycerols as feedstocks for biofuel production: perspectives and advances. Plant J 54(4):621-639

Jenkins LS, Nunn WD (1987) Genetic and molecular characterization of the genes involved in short-chain fatty acid degradation in Escherichia coli: the ato system. J Bacteriol 169(1):42-52

Katashkina JI, Skorokhodova AY, Zimenkov DV, Gulevich AY, Minaeva NI, Doroshenko VG, Biryukova IV, Mashko SV (2005) Tuning the expression level of a gene located on a bacterial chromosome. Mol Biol 39(5):719-726

Kikuchi Y, Kojima H, Tanaka T, Takatsuka Y, Kamio Y (1997) Characterization of second lysine decarboxylase isolated from Escherichia coli. J Bacteriol 179(14):4486-4492

Kojima H, Ogawa Y, Kawamura K, Sano K (1994) Treaty patent WO95/ 16042. International Patent Cooperation

Korshunov S, Imlay JA (2010) Two sources of endogenous hydrogen peroxide in Escherichia coli. Mol Microbiol 75(6):1389-1401

Leuchtenberger W, Huthmacher K, Drauz K (2005) Biotechnological production of amino acids and derivatives: current status and prospects. Appl Microbiol Biotechnol 69(1):1-8

Magnuson K, Jackowski S, Rock CO, Cronan JE Jr (1993) Regulation of fatty acid biosynthesis in Escherichia coli. Microbiol Rev 57(3): 522-542

Maisonneuve E, Fraysse L, Lignon S, Capron L, Dukan S (2008) Carbonylated proteins are detectable only in a degradationresistant aggregate state in Escherichia coli. J Bacteriol 190(20): 6609-6614

Malik A, Sakamoto M, Hanazaki S, Osawa M, Suzuki T, Tochigi M, Kakii K (2003) Coaggregation among nonflocculating bacteria isolated from activated sludge. Appl Environ Microbiol 69(10):6056-6063

Messner KR, Imlay JA (2002) Mechanism of superoxide and hydrogen peroxide formation by fumarate reductase, succinate dehydrogenase, and aspartate oxidase. J Biol Chem 277(45):42563-42571

Miller JH (1992) A short course in bacterial genetics. Cold Spring Harbor Laboratory Press, Cold Spring Harbor

Nachin L, Nannmark U, Nyström T (2005) Differential roles of the universal stress proteins of Escherichia coli in oxidative stress resistance, adhesion, and motility. J Bacteriol 187(18):6265-6272 
Pradenas GA, Paillavil BA, Reyes-Cerpa S, Pérez-Donoso JM, Vásquez CC (2012) Reduction of the monounsaturated fatty acid content of Escherichia coli results in increased resistance to oxidative damage. Microbiology 158(5):1279-1283

Raba J, Mottola HA (1995) Glucose oxidase as an analytical reagent. Crit Rev Anal Chem 25(1):1-42

Resnik E, Pan B, Ramani N, Freundlich M, LaPorte DC (1996) Integration host factor amplifies the induction of the aceBAK operon of Escherichia coli by relieving IclR repression. J Bacteriol 178(9): 2715-2717

Rosenberg JN, Oyler GA, Wilkinson L, Betenbaugh MJ (2008) A green light for engineered algae: redirecting metabolism to fuel a biotechnology revolution. Curr Opin Biotechnol 19(5):430-436
Service RF (2009) ExxonMobil fuels Venter's efforts to run vehicles on algae-based oil. Science 325(5939):379

Wendisch VF, Bott M, Eikmanns BJ (2006) Metabolic engineering of Escherichia coli and Corynebacterium glutamicum for biotechnological production of organic acids and amino acids. Curr Opin Microbiol 9(3):268-274

$\mathrm{Xu}$ Y, Heath RJ, Li Z, Rock CO, White SW (2001) The FadR.DNA complex. Transcriptional control of fatty acid metabolism in Escherichia coli. J Biol Chem 276(20): 17373-17379

Zheng M, Åslund F, Storz G (1998) Activation of the OxyR transcription factor by reversible disulfide bond formation. Science 179(5357): $1718-1721$ 